\title{
Reclaiming space for learning in liturgical contexts: Cracks in the maxim of the uselessness of liturgical ritual
}

\author{
Authors: \\ Marcel Barnard ${ }^{1,2}$ \\ Cas Wepener ${ }^{1}$ \\ Affiliations: \\ ${ }^{1}$ Department of Practical \\ Theology, University of \\ Pretoria, South Africa \\ ${ }^{2}$ Department of Practical \\ Theology, Protestant \\ Theological University, \\ the Netherlands and VU \\ University Amsterdam, the \\ Netherlands \\ Note: \\ Prof. Dr Marcel Barnard is \\ participating as research \\ associate of Prof. Dr Cas \\ Wepener, Department of \\ Practical Theology, University \\ of Pretoria, South Africa. He \\ is professor extraordinary in \\ the Department of Practical \\ Theology, University of \\ Stellenbosch.
}

This article is published in the section Practical Theology of the Society for Practical Theology in South Africa.

\section{Correspondence to:}

Marcel Barnard

Email:

mbarnard@pthu.nl

\section{Postal address:}

Postbus 80105, 3508TC

Utrecht, the Netherlands

Dates:

Received: 10 Oct. 2011

Accepted: 27 Feb. 2012

Published: 18 July 2012

How to cite this article: Barnard, M. \& Wepener, C., 2012, 'Reclaiming space for learning in liturgical contexts: Cracks in the maxim of the uselessness of liturgical ritual', HTS Teologiese Studies/Theological Studies 68(2), Art. \#1184, 8 pages. http://dx.doi.org/10.4102/ hts.v68i2.1184

(C) 2012. The Authors. Licensee: AOSIS OpenJournals. This work is licensed under the Creative Commons Attribution License.
The problem addressed in this article is, that empirical and theoretical research appears to demonstrate that liturgy often aims at certain results. This, however, puts the widely accepted notion in Liturgical Studies of the so-called uselessness of liturgical ritual under pressure. Against this background in Liturgical Studies the aim of this article is to reclaim space in academic discourses on liturgy for learning in liturgical contexts. The latter is done by presenting several liturgical models, revisiting arguments regarding the (non) functionality of ritual or religion and also by reflecting on ritual-liturgical data that the authors personally collected as part of two research projects.

\section{Introduction}

\section{Reclaiming space for learning in liturgical contexts ${ }^{1}$}

The problem addressed in this article is, that empirical and theoretical research appears to demonstrate that liturgy often aims at certain (learning, bonding etc.) results. This, however, puts the 'basic rule' (cf. Post 2001a:43) in Liturgical Studies under pressure, that liturgy is useless and beautiful, 'juggling with clouds', 'the play of a child'. Cilliers (2008) refers to the 'niefunksionaliteit' [non-functionality] of worship. Against this background in Liturgical Studies the aim of this article ${ }^{2}$ is to reclaim space in academic discourses on liturgy for learning in liturgical contexts. This also corresponds to the particular identity of Protestant worship.

The question we address is: when is the starting point of gratuity so strained that there is no question of gratuitous worship any longer? And the background is the fact that the boundaries between different religious and social practices are becoming more fluid. This holds for instance for worship and formation (cf. Sonnenberg \& Barnard 2012) and also for worship and social capital building (cf. Wepener \& Cilliers 2010). Congregational Studies, Liturgical Studies, Formation and Pastoral Care may rather be regarded as perspectives of practices of faith, than as independent disciplines that relate to a particular domain. Firstly we will explore and expose what we will call cracks in the maxim of uselessness of worship/liturgy/ritual. Thereafter we will illustrate it by means of two ritual-liturgical examples and lastly we will conclude by bringing the theoretical and empirical insights together. We will here thus firstly critically discuss the maxim that rituals and liturgy are useless, without giving it up entirely, and concomitantly goals that in the literature are attributed to worship will be explored. Five goals of Christian worship will be formulated and we will elaborate on one case, related to a research project concerning the relation of social capital formation and liturgical ritual ${ }^{3}$, before we conclude.

\section{Cracks in the maxim of the uselessness of liturgical ritual Introduction}

In our study we learned that liturgy is useless. Rituals have no end and serve no aim; they have no function and are not productive. That does not mean that they are superfluous and can be missed. There are especially two strong images by which our professors used to elucidate the uselessness as well as, at the same time, the necessity of liturgical rituals. Liturgical rituals, one of them said, are just as useful as to pick up someone from the airport who is very well able to carry her own suitcase. Another lecturer said that rituals are just as useful as to present a bridal couple with a set of fine silver teaspoons, whilst four-in-a-dollar stainless steel copies would do quite well to stir the tea. Liturgy and ritual have no purpose, they are gratuit, and we perform them for no reason.

1.This material is based upon work supported by the South African National Research Foundation (NRF) under Grant number 73974. Any opinion, findings and conclusions or recommendations expressed in this material are those of the author and therefore the NRF does not accept any liability in regard thereto.

2.Cf. also Sonnenberg and Barnard (2012) where the same theme is elaborated on, but with specific reference to youth worship.

3.For a general outline of the project see Wepener et al. (2010:61-82). 
Within Liturgical and Ritual Studies this rule serves as a maxim, a subjective rule. ${ }^{4}$ Paul Post speaks of 'a basic code': 'rituals are useless and beautiful ... Ritual action is time wasted; it is the same as the play of a child, the moving of angels, juggling with clouds' (Post 2001a:40). This remark is made against the background of a growing functionalising of ritual. The anthropologist Staal ([1979] 1996:490) complains that 'rituals, instead of remaining useless and pure, became useful and meritorious'. The idea of liturgy as useless is connected to definitions of liturgy as ritual and play before God (Guardini 1959:102). Elsewhere Post qualified uselessness as a characteristic of ritual play compared to the everyday in which functionality reigns (Post 2001b:76). Guardini, in his famous Vom Geist der Liturgie (The Spirit of Liturgy), and Lang in his Sacred Games: A History of Christian Worship, both refer to Plato: 'We should pass our lives in the playing of games - certain games, that is, sacrifice, song, and dance - with the result of ability to gain heaven's grace' (Guardini 1959; Lang 1997; Plato in Lang 1997:viii). Guardini (1959), like others, connects liturgy with the arts, and asks:

Has art any aim or purpose? No it has not ... The work of art has no purpose, but it has meaning -'ut sit' - that it should exist, and that it should clothe in clear and genuine form the essence of things and the inner life of the human artist. It is merely to be 'splendor veritatis', the glory of the truth ... Liturgy has no purpose, but it is full of profound meaning. It is not work, but play. To be at play, or to fashion a work of art in God's sight - not to create, but to exist such is the essence of the liturgy. (pp. 64, 70)

Not only pagan and Roman Catholic sources define liturgy as play. Also the Anabaptist Johan Huizinga, in his wellknown Homo Ludens argues that cult and religion can be characterised as play, and says that play is disinterested and gratuitous, but also indispensable (Huizinga 1940:29-41, 13f.). The reformed theologian Johan Cilliers (2008) speaks of the 'nie-funksionaliteit van die erediens' (non-functionality of worship 2008; so do Barnard \& Postma; Barnard \& Postma 2007). In general, we can say that the Protestant tradition has been careful to identify the act of glorifying God through human worship with doing a meritorious good work. Worship is probably 'profitable unto tranquillity and good order in the Church', but is not 'necessary to salvation' (Augsburg Confession XV). The glorificatio rests in the gloria Dei, which is self-sufficient. However, especially some Reformed theologians have a counter-voice in this regard. The Dutch theologian Arnold van Ruler in his book Waarom zou ik naar de kerkgaan? [Why should I go to church?], answers the question by giving 21 reasons (Van Ruler 1970). The South African theologian Dirkie Smit formulated eight functions of liturgical ritual in South African contexts: subversion, liberation, community, articulation, calling, formation, transformation and confirmation, commitment (Smit 2004). We will show in this article that they are, to a certain degree, correct.

4.We mean 'maxim' in the sense of Immanuel Kant in his Kritik der reinen Vernunft (1787:694) 'Ich nenne in the sense of Immanuel Kant in his Kritik der reinen Vernunt (1787:694) 'ch n' in the allenaffenheit des Objekts, möglichen Volkmmommen sind, Maximen der Vernunft. So gibt es Maximen der spekulativen Vernunft, die lediglich auf dem spekulativen Interesse derselben beruhen, ob es zwar scheinen mag, sie wären objektive Prinzipien.'
In this article we will show that the maxim of the uselessness of liturgical ritual has to be nuanced. How and to what extend can useless liturgical ritual be called functional? In spite of the common understanding of the essence of liturgical ritual as useless, our understanding of the maxim began to prove little cracks, which have widened in the course of time.

\section{Aims attributed to worship in various contexts}

\section{The classical reformed model}

The first crack appeared when we reconsidered our Reformed background. The classical liturgical model of the reformed tradition is purpose driven. The Catechism of Heidelberg ( $\mathrm{HC}$ ) discusses the liturgy in the framework of the Fourth Commandment, identifies it with the sermon and emphasises the education of the worshippers. The service is primarily an exercise in faith that aims at steering clear of evil doing. ${ }^{5}$ Liturgy is a lecture that draws the attention of the congregation to a life of gratitude, which is characterised by doing good works. From a societal perspective gratefulness is aimless, but this aimlessness is counterbalanced by good works. The church service has a practical intention and aims at a change of behaviour or, in other words, a praxis in accordance with (Reformed) Christian faith. Further, liturgy has also a cognitive target, viz. 'a certain knowledge, whereby I hold for truth all that God has revealed unto us in his word. ${ }^{6}$ The adverb 'cognitive' should not exclusively be interpreted as 'rational'. The knowledge, which the liturgy aims at, is meaningless if not the Holy Spirit alleviates the knowledge of the gospel to faith and trust in the grace of Jesus Christ that in its turn results in Christian diaconal acting.

\section{Evangelical worship}

The second crack appeared as a result of the breaking through of evangelical and charismatic streams in our churches and as a consequence also in its liturgical ritual. This was a much broader crack than the first one. The American scholar Sally Morgenthaler (1995:39), herself an evangelical, says: 'The true goal of evangelism is to produce more and better worshippers.' The church service serves the 'praise and worship' of God. Morgenthaler however is a critical voice in a movement that she diagnoses as a 'Non-worship epidemic' (1995:50), in which churchgoers are treated more as public than as participants. She typifies the Willow Creek Seekers services as 'pre-evangelistic entertainment, a highly captivating, sixty minute "informercial" for Christianity" (1995:47). Bethel Müller (2008:63) however emphasises that missional liturgy is not 'about legitimising the ideological presuppositions embedded in every culture', but about 'transforming in the sense of Romans 12:2f'.

Morgenthaler's criticism is first and foremost an internal discussion amongst evangelicals, that we do not want to assess, but which we understand when we read the typical diptych of Rick Warren - the evangelical or Southern Baptist

5.HC, S. $38,0.103$.

6.HC, S.7, Q. 21

7.Compare in this regard also Wepener (2008:206-219). 
senior pastor of the Saddleback (mega-) Church in California - The Purpose Driven Church (1995) and The Purpose Driven Life (2002). Warren defends entertainment as a function of the evangelical commission 'to attract the crowds' (cf. Warren 1995:207-238) and says that to entertain does not mean anything else than 'capturing and holding the attention for an extended period of time' (Warren 1995:231). The purpose of especially seeker services is 'to specialise your services according to their purpose.' This purpose depends on who the audiences are, either 'unchurched friends' or 'believers' (Warren 1995:245). The goal of the seeker services that Warren offers in his church is to reach unbelievers for Christ, 'to be spiritually restored and emotionally recharged' (Warren 1995:272), and ultimately, to create people who worship God (cf. Warren 1995:242). In summary, for Warren the goal of worship is missionary and the method is to entertain the 'unchurched' and to make them feel comfortable in church by all possible means: parking places close to the building, people who guide them, comfortable chairs, a music style that refers to what they daily hear, and a 'speed up' pace and streaming flow in the entire service that reflect late-modern life.

Before discussing the third and most elementary crack in the maxim of the uselessness of liturgy, we want to weigh up the first two cracks. The classical Reformed tradition appears to seek a careful balance between on the one hand the aimlessness of gratitude and on the other hand the aim of behaviour transformation and the generation of faith knowledge. This balance can easily be disturbed, as is seen in the evangelical tradition and end up in an exaggerated functional understanding of liturgy: a commercial-styled advertising of Christian faith. However, Morgenthaler also formulates the aim of worship primarily in missionary terms. Warren adds a psychological and spiritual aspect to this when he aims at spiritual restoration and an emotional recharge. The evangelical movement appears to seek a balance between mission and entertainment - mission being the necessary target of the church in days of de-churching and entertainment the phenomenon that attracts the crowds. We are reminded that also the 16th century Reformation sought a missionary target of the church service: the sermon was exemplified as 'publice docere', public education (CA 14; conf. Calvin, Inst. IV.I.19).

\section{Worship in the context of poverty}

The third crack in the maxim of the uselessness of liturgy has widened into a rift in the course of time. It originated in the context of South Africa. Various observations resulted in the hypothesis that the participation in Christian liturgical ritual could contribute to the formation of social capital and, as a consequence, eventually and indirectly in poverty alleviation. We became convinced, that worship in the context of post-apartheid South Africa should aim at human flourishing (cf. Pieterse 2001; Wepener et al. 2010; Wepener \& Cilliers 2004, 2010; Wepener 2010a, 2010b). This case will be elaborated exemplarily further on in this article (Section the case of liturgical ritual in Mlazi and Langa).

\section{Functions of liturgical ritual}

The classical Reformed emphasis on the generation of faith knowledge and transformation of behaviour is understandable in its rooting in the time of the Reformation and against the background of the Roman Catholic Church of those days. The missionary goal of evangelical liturgy is explicable in a time of secularisation, mainly in the Western world. In the context of post-apartheid South Africa, the goal of liturgy may be defined in terms of social justice and human flourishing. Three different liturgical forms that originated in three different societal and ecclesial contexts and implicitly drive at three different goals have caused cracks and rifts in our understanding of the maxim of the uselessness of liturgy. We will see however, that in all cases liturgy is not meant to be instrumental to achieve the specific goals, neither is the purpose-driven aspect of liturgical ritual dominant in liturgical performances. In summary, the stories of the suitcase at the airport and of the silver teaspoons have to be nuanced. We pose the thesis that liturgical ritual is no function of whatever goal, but nevertheless serves certain aims. We collect the following concrete and closely related aims from the examples that we just gave. These aims are not meant to be normative and exclusive, but heuristic values that we use in this article to build up some theory concerning functional aspects of liturgical ritual:

- Liturgy aims at a transformation of behaviour and at knowledge of the grace of God as it is revealed in the life, death and resurrection of Jesus Christ. Nota bene: this transformation and knowledge should not only be searched for exclusively in the rational spectre, but are supposed to be found in the fields of knowledge, skills and attitudes, experiences and affections (see also in section the social-cultural function of liturgical ritual). Liturgicalritual knowledge often is bodily-based.

- The liturgical ritual aims at the well-being and also welfare of its participants, in short, aims at human flourishing.

- Liturgy aims at creating worshippers.

- The church service aims at being inviting and public.

- Worship should be spiritually restoring and emotionally recharging.

These aims bring us to the dimensions of religion.

\section{The aims of liturgical ritual refer to different dimensions of religion}

Overseeing this short list of aims attributed to liturgical ritual, it is obvious that the formulated aims are different in shape. They refer to different dimensions of religion as a whole. Glock and Smart (cf. Auffahrt \& Mohr 2006:1611) discern six dimensions of religion: the intellectual/ideological/ cognitive dimension, the dimension of social ethics, the ritual dimension, the institutional, the aesthetic and the psychic dimensions. The aims attributed to performing worship as we deduced them from our cases, can be distributed over some of these six dimensions. In other words, the ritual dimension of religion includes aspects of the other dimensions that the six facets of Glock and Smart partly cover (Auffahrt \& Mohr 2006:1611). 
To acquire knowledge of God's grace is amongst other things a cognitive aim. The transformation of behaviour refers to a social-ethical objective. The aiming of liturgy at human flourishing refers to the social-ethical dimensions of religion as well. To be a worshipper is primarily an aesthetical aim, although this aim cannot be seen independently of cognitive and ethical targets. Still, to be a worshipper asks for some capabilities in singing and perhaps also in dancing, that is, asks for musical and bodily skills. The quest of liturgy to be inviting may refer to different dimensions of religion, viz. the facet of social ethics but also the cognitive or ideological aspect. The pursuit of a spiritually restoring and emotionally recharging liturgy refers mainly to the psychological domain.

In conclusion, liturgical ritual bears traces of the ideological or cognitive, social-ethical, aesthetical and psychological qualities of religion and has functional purposes with regard to these domains. Liturgical-ritual functions concern the truth, the good and the beautiful, as well as the human mind. On these fields liturgy is not completely useless, but serves certain aims. We will highlight this in the rest of this article by focussing on the socio-cultural function of liturgical ritual.

\section{The social-cultural function of liturgical ritual ${ }^{8}$}

We will focus now on the social ethical aspect of liturgy, referring to the third example that we presented, namely religious ritual and social capital formation. We developed the hypothesis that religious ritual helps to generate social capital; this hypothesis starts from a social-cultural perspective of religion as a whole, pushing other aspects into the background. We are well aware that this is a reduction. We are at the same time convinced that the social-ethical dimension of liturgy is part of the kernel of Christian liturgy: the theological concept of koinonia, community, clearly has a social dimension (cf. Brouwer 2009). In short, religion is in our research primarily defined as a 'social pattern for act and attitude', or, with Clifford Geertz (cf. Auffahrt \& Mohr 2006:1614, 1612), as 'a cultural text'.

Platvoet (2007:197) rightly says that the social and psychological functions of ritual may not be identified with functionalism. When we speak of functions of ritual, we do not mean that every liturgical meeting should be directly relevant, but that liturgical ritual has an ambiguous relation to the social order and, as a consequence, may be able to contribute - in a positive or in a negative way - to social capital formation. To analyse these functions, it is helpful to distinguish different aspects of qualities of ritual.

Cilliers and Wepener (2007:47-54) have suggested that several dimensions, qualities and processes of liturgical ritual indeed contribute to the formation of social capital. They accurately refer to a much-cited page in Ronald L. Grimes'

8.The sections the social-cultural function of liturgical ritual and the case of liturgical ritual in Mlazi and Langa of this article will be more elaborated. They will be included in Marcel Barnard, Henry Mbaya, Cas Wepener, 'Blessing, Burning and Burying. Social Capital Formation in Churches in South Africa', accepted, in W. Gräb et al. (eds.), title not yet known, LIT Verlag, Zürich/Berlin, forthcoming.
Ritual Criticism (1990:14). The page holds a table of so-called qualities of ritual. Qualities are aspects, characteristics or dimensions of ritual. They are definitively not meant as definitions, but indeed as characteristics that in their extensiveness are more complete than any definition, and that each alone are not unique to ritual. 'When these qualities begin to multiply, when an activity becomes dense with them, it becomes increasingly proper to speak of it as ritualised, if not a rite as such' (Grimes 1990:14). ${ }^{9}$ Thus, activities are more or less ritualised, or can eventually be called rites. It is here not the place to list all of Grimes' qualities, but we limit the catalogue to those that refer to, either positively or negatively, functional characteristics. We quote:

- symbolic, referential (not merely technological or primarily means-oriented)

- mystical, transcendent, religious, cosmic (not secular of merely empirical)

- adaptive, functional (not obsessional, neurotic, dysfunctional). (Grimes 1990:14)

The symbolic and referential on the one hand and the technological and means-end oriented on the other hand are opposed in this scheme. Liturgical rite is not open to only one singular well-defined goal and one singular meaning, but it is open to interpretations in which other domains come into view in a way that is beyond control and cannot be steered. The rite is no technique with which specific predestined goals can be attained. An empirical approach is therefore insufficient to let the ritual 'work'; performing rites asks for poetic and/or religious attitudes. It demands artistic, aesthetical skills as well, in short, openness to the transcendent and the mystical. However, ritual has to be adaptive and functional. We understand that as suitable for this or that person or group of persons, in this or that particular situation, geographically, historically, ecologically, genetically, economically and physiologically. Otherwise, it is 'unhealthy', or, 'to repeat Grimes' list of mental disorders, 'obsessional, neurotic or dysfunctional'. One description of the ritual of Holy Supper in the Dutch Reformed Church in South Africa during apartheid, may serve as an example of a rite that was not adaptive and functional, and as a consequence, unhealthy (cf. Wepener 2002).

Referring to Grimes' table, Cilliers and Wepener (2007:47-53) sum up the following elements of liturgical ritual that contribute to social capital formation:

- liturgical ritual generates and stimulates a sense of belonging and relationships of trust

- liturgy helps to develop skills (viz. [musical] performing skills, skills to participate in and chair a meeting)

- liturgical ritual may create an awareness of material needs or develop a critical attitude toward the cause of poverty of the participants

- liturgical ritual produces collaborative opportunities to further real transformation.

At this stage it is necessary to illustrate our argument by means of ritual data from the South African context. In this

9.At the beginning of the 21st century, when 'emerging rituals' became a topic in Ritual Studies, Grimes added the notion of 'ritualizing' as 'the activity of deliberately cultivating or inventing rites' to his conceptual registers (cf. Grimes 2000:29). 
regard we focus on an African Independent Church (AIC) worship service in Mlazi, Durban as well as liturgical rituals related to a funeral in a Uniting Reformed Church in Langa, Cape Town.

\section{The case of liturgical ritual in Mlazi and Langa}

In this section ritual data will be presented which will illustrate and substantiate our line of argumentation by focussing on the third example mentioned, namely worship in the context of poverty and therefore as such on the social-ethical dimension of liturgical ritual. Firstly we present in bullet format a brief description of an annual AIC worship service called the Isitisha, documented by means of participatory observation in Mlazi at the end of October 2010 and secondly a description of funeral rituals as performed by members of Reformed churches in Langa documented during field work in that area mid-2003. Thereafter some concluding remarks will be made.

\section{Isitshisa, Mlazi, Durban, KwaZulu-Natal}

The so-called Isitshisa is an annual worship service of the Corinthian Church of South Africa. Once a year this specific AIC's congregations gather to celebrate this service as their founder, Johannes Richmond, has commanded them to do. In essence the service consists of the following features: ${ }^{10}$

- Participants gather on the last Saturday evening of October for an all-night service.

- One by one as they arrive from various parts of South Africa, congregations dance into the church, bringing money to the table and food that is stored in a room next to the stage in front.

- When all have arrived various initiation rites occur, for example, new members of women's leagues are initiated.

- Starting in the early hours of the morning several sheep get slaughtered and the meat cooked.

- As a climax of the service during the early hours of the morning, a calf is sacrificed. First an altar of rocks is built upon which large pieces of wood are laid, a fire is lit, the heifer's throat slit and thereafter burnt.

- After the burnt offering a bus full of poor blind people arrive. They share the meal that was cooked with the Corinthians and thereafter the money and the food that was brought to the service, is donated to the visitors by this denomination.

\section{Langa, Cape Town, Western Cape}

From Mlazi in KwaZulu-Natal we move to the South of the country and specifically the oldest township of Cape Town, called Langa where we also conducted participatory observation regarding rituals.

It was a Saturday morning in Langa. ${ }^{11}$ People were starting to arrive at the funeral service of the wife of one of the elder's

10.For a more detailed description of this service, see Mbaya (2011).

11.Description taken from Wepener (2004:527), who also performed the participatory observation. of a Xhosa-speaking Reformed congregation. Actually the ceremony or liturgy had already started the previous evening with a prayer service and the men slaughtering the sheep and the women starting to prepare food. In the week preceding the funeral, the deceased's husband also collected money from friends and family to pay for the funeral, even the researcher doing liturgical fieldwork was told exactly how much he owed. ${ }^{12}$ Meanwhile, whilst the preparation of the food continued in the church hall, in the church itself an organ was playing well known Reformed melodies apt for a funeral service in this worship space which was in a typical Western-style church building, slowly filling up with hundreds of people.

The funeral service itself included much hymn singing, a very long sermon and several eulogies about the deceased that continued for several hours. After the funeral service the procession moved to the graveyard and thereafter everyone was invited to a meal at the church consisting of rice and mutton stew. In Xhosa tradition the tombstone will only be revealed at a later stage in another ceremony, so the communal meal concluded the day's proceedings. For the direct family of the deceased there were still several rituals that would follow this funeral service in the weeks to come. Two of these included 'to drink water' and 'the washing of the pick axes' which are the main foci of our description in this article.

The former ritual, also called 'the Feast of Amanzi (water)' is conducted the day after the funeral. For this ritual a sheep must be bought and slaughtered for use on this particular Sunday after the funeral service especially, just for the immediate family. According to members from this specific congregation, in Xhosa culture when a person has had a big fright they give him water to drink. ${ }^{13}$ The name of this ritual is thus symbolic, in the sense that it is aimed at 'calming' (comforting) the family after the 'fright' (death of the mother) they got. And the main part of this ritual is the eating of the meat of the freshly slaughtered sheep together as a family. According to the deceased's husband this ritual is extremely important for the family to once again take hands after they have been weakened as a group by the passing away of the mother and this ritual meal serves the purpose of strengthening these damaged group ties.

The second ritual is conducted several weeks later and the name is once again a symbolic reference and not a literal washing of pick axes. The 'mud' (death) that is still 'sticking' to the pick axes that were used to dig the grave must be washed away. If this is not done this mud, that is still clinging to the pick axes, will make the people in that family and community die soon. The ritual of the 'washing of the pick axes' includes a feast for which a large amount of traditional beer (umqombothi) is brewed and the whole community is invited. Where the first ritual of eating, only the immediate

12. When you are told, not asked, you know you have moved from observation to participatory observation.

13.In some other cultures known to the authors, it is sugar water that is given to calm the person down. 
family took part, this ritual of drinking is for the family and the local community. ${ }^{14}$

Except for the unveiling of the tombstone that will still be performed at a later stage, this concludes the performance of rituals related to this person's death in Langa. However, although the people are already performing these rituals, there is also a geographical 'not yet' present, pertaining to land of their ancestors where they long to perform their rituals. To quote one of the Xhosa ministers of this congregation regarding the performance of their rituals in Langa:

Yes, we perform all our rituals here in the township, but one day, one day when we get the land of our ancestors in Eastern Cape back by means of our land claims, then and there we will be performing the real rituals. (Unknown Xhosa minister)

\section{Some provisional conclusions from the case of liturgical ritual in Mlazi and Langa}

Do these rituals have functional qualities, viz., do they attribute to social capital building? Do the rituals aim at human flourishing in general and the well-being and welfare of its participants? We briefly summarise some of our conclusions. The first three are from an emic point of view, the last two from an etic perspective. ${ }^{15}$

Firstly, according to an emic point of view misfortune, illness and unemployment have spiritual causations. Generally spoken, liturgical rituals are a direct way of coping with the spirits, and there is a strong sense of the rituals' mechanical way of working.

Secondly, according to the emic perspective, the church and the family play a major role in the high self-esteem of people. It is the church that gives them healing, friendship, assistance and support if they are in need.

Thirdly, from an emic point of view, AICs have an empowering function for 'poor' people. They can come into AICs and become important within the congregations through the responsibilities that they are given. In the observed and described liturgical rituals we clearly see the phenomenon of role taking: ministers, secretaries, musicians and lectors are not professionally trained or only in a very limited way. They receive their training mainly in church.

Fourthly, we can point to some directly functional aspects of the observed and described liturgical rituals. The aim of the Feast of Amanzi in Langa is clearly to strengthen the group ties that were weakened by the death of a family member. The same holds for the ritual of the washing of the pick axes. It reconnects people to the community, especially the people directly affected by the passing away of a loved one. Also the yearly Isitshisa (or burning of the heifer) festival has some

14.Members of the Corinthian Church indicated during our fieldwork, that they also perform these two rituals.

15.'Emic and etic distinguish the understanding of cultural representations from the point of view of a native of the culture (emic) from the understanding of cultural representations from the point of view of an outside observer of the culture (etic)' - Michael Rhum, 'emic and etic' see Barfield (1997:148). The authors of this article are aware of the sensitivities that the notion of 'native' in the context of South are aware of the
Africa can evoke. direct functional elements in it. It is performed to re-establish solidarity in a broad sense, that is, including friendliness, brotherhood, et cetera. The emphasis on brotherhood or friendship must be evaluated from the perspective of African world views and values that stress the importance of the extended family. Hence, here the interface of religion and culture is strong. The festival is about offering, and the diaconal element of the festival - giving to the blind - is meant to spread over the whole area in which the church is active. People establish and re-establish their structures at the festivals. From the perspective of social capital formation the role of the general secretary is also important: he makes the infrastructure and - to say it in a modern way - monitors, together with the local secretaries, the process of solidarity in the entire church. Healing and directly functional aspects of liturgical ritual can be called 'formal functions' of ritual: 'risk management', according to Günter Thomas. Moreover, there also are 'final functions' that confirm or undermine the established order. Often, these final functions are beyond the knowledge and control of the participants (Thomas 2006:341).

Fifthly, in this respect one can critically introduce the standard question regarding a functional approach to religious ritual: does the ritual not confirm and re-establish societal and global structures in which the poor are being confirmed in being poor? In other words, does the liturgical ritual not reproduce injustice and insincerity? Or, to put it another way, how critical are the rituals with regard to the status quo? The blind people who are invited to the festival of the Burning of the Heifer called the Isitshisa - a phenomenon that has existed since the fifties of the last century; the founder ordered so in his last days, receive donations in the form of food that is brought into the festive liturgical ritual from all congregations.

The exemplary rite of donation focuses on the blind, because they were and are seen as marginalised people. According to our interviewees, members of the church spiritually connect to the people in need in this way. One can ask however, whether this does not reconfirm the blind as marginalised people every year. In the fifties the blind were selected as a marginalised group that received aid from the church at the Isitshisa (or Burning of the Heifer) festival. But who wants to be staged as icon of marginalised people year after year? Does the festival unintentionally reaffirm societal injustice, instead of alleviating poverty? Or has the position of the blind in Africa simply not changed over the last sixty years?

\section{In conclusion}

We posed that the maxim of the uselessness of liturgical ritual has to be nuanced. The question to be answered was: how and to what extend can liturgical ritual be called functional? Liturgical ritual is pointless, 'juggling with clouds', like a play. Worship has its aim in itself. That does not mean that it has no functional qualities. This holds in the first place for the liturgical ritual as a whole. Admittedly some scholars may come to different conclusions than we do in this regard, therefore we lastly and shortly elaborate on 
the epistemological basis underlying our approach within the field of Liturgical and Ritual Studies.

Based on her liturgical musical ethnographic research in African-American worship contexts in the United States of America (USA), Mary McGann (2010:94-95) concludes that this specific tradition is based on a 'functional aesthetic that assumes that music is meant to do something - to move, to touch, to heal; and that herein lies its meaningfulness.' This also holds true for the liturgical ethnographic work that is currently conducted in the framework of the NRF project on religious rituals and social capital formation. Worship has a formative power in shaping believers, more specifically Christian believers, because it evokes and expresses basic attitudes that enable faith. Worship is the learning environment in which we become Christians through the power of ritual. The language of liturgical-ritual is primarily 'performing non-cognitive' (Astley 1984). Only within the spiritual implicit learning milieu of worship, more explicit cognitive knowledge can be communicated. But in order to be able to come to this conclusion that attempts to broaden the traditional view of the exclusively non-functional nature of all liturgical-ritual, a fundamental difference regarding the epistemological basis for approaching the phenomenon of liturgical ritual in the context of research was needed.

Theodore Jennings Jnr (1996) writes in his well known article entitled 'On Ritual Knowledge' that when one approaches ritual scientifically a ritually based epistemology is needed. This is so because according to him ritual serves a noetic function and the functional qualities of ritual that are indeed implicit in liturgical ritual, function on the level of intuitive thinking. To quote Jennings (1996:327): 'It is not so much that mind "embodies" itself, but rather that the body "minds" itself or attends through itself in ritual action.' And if this is the epistemological basis on which the phenomenon is approached then it should have a huge impact on the research methodology. Then firstly a study of the fully enacted ritual in its multiple contexts is imperative and methods such as participatory observation or, as in the case of McGann's liturgical musical ethnography, are non-negotiable and can scholars, who observe liturgical ritual in a non-participatory fashion not come to the same conclusions about the functional dimensions of liturgical ritual as scholars who do adhere to this more corporeal bodily-based epistemology. Reading about Isitshisa in a textbook is one thing, but participating in this event is quite another.

Walking around during the service talking to participants who exclaim 'I cannot explain in words how I feel about being in this place tonight' and another saying 'what I experience here in Mlazi I take back to Phepheni, to the members who could not come ${ }^{\prime 16}$ is quite another experience, let alone how your own body is 'minding itself' around 3 o'clock in the morning in Mlazi whilst numerous horns are blowing, drums are beating, people are singing and dancing and October 2010. many sheep are being slaughtered. Where is the meaning of a worship service such as this one to be placed? Can we speak of a meaning that can, in a systematic theological fashion, be explained? Or do we work here with a dynamic meaningmaking process which is constantly in flux, in which the meaning of liturgical ritual constantly oscillates between the ebb and flow of functional and non-functional qualities?

Some functional aspects of liturgical ritual that we deduced from our observations of classical reformed liturgy, evangelical worship and worship in the context of poverty in South Africa appeared to refer to qualities of religion as they were formulated by Glock and Smart (cf. Auffahrt \& Mohr 2006:1611). These are the intellectual/ideological/cognitive, the social-ethical, aesthetical and psychological qualities. In our terms, functional aspects of liturgical ritual refer to the classical triad of the true, the good and the beautiful, as well as the human mind. In summary, functional aspects of liturgical ritual refer to the entire act of worship and to its participants. Different denominational groups emphasise different aspects, but all within the framework of an implicit spiritual learning environment. In functional terms we can say that ritual has a pedagogical nature, because as Jennings (cf. 1996:324-334) puts it, ritual is a way of gaining, transmitting and displaying knowledge. Although liturgical ritual often seems unchanging at closer look there are always slight changes. These changes are signs of ritual's way of searching for knowledge by means of performance. At the same time much of liturgical ritual stays the same, because of its repetitive nature, and here lies part of the way in which ritual transmits knowledge. And lastly in the performance there is also the display of knowledge, for example how some rituals in a sense 'repeat the act which founds the world' and which Jennings calls an 'ontological praxis'. In order to explain this Jennings (1996:327) quotes Van der Leeuw who quotes Lucian, and it is here again quoted in this article to once again attempt to formulate an argument regarding liturgical ritual to a non-participatory rationally inclined reading audience: 'He who does not dance does not know what will happen.'

In this article we have focussed on the social-ethical functions of liturgical ritual, taking worship in a context of poverty in South Africa as exemplarily. As researchers we want to know how worship is related to this context, whilst we suppose that participating in worship by worshippers helps to alleviate poverty. We further hope that the research itself will have an emancipatory effect on the research field. This is confirmed by first research results. The often costly and quite elaborate African funeral tradition is sometimes criticised in contexts of poverty, because of the huge cost implications of these ceremonies. The description of the various liturgical rituals performed during a funeral service and thereafter in Langa prompts us to look at the value of these rituals not only from a perspective involving financial expenditure in the traditional sense of the word, but maybe rather from a social-capital perspective. How much is the bonding and bridging that occurs during and after the funeral worth in 
monetary terms? And is the description of these rituals not pointing towards the social dimension of ritual that has indeed some functional qualities embedded in it? It appeared helpful to direct our attention to some specific qualities of liturgical ritual.

Some of the aspects of ritual that Ronald Grimes lists are important markers in the research project. The symbolic or referential and the mystical or transcendental aspects warn us not to see liturgical ritual as an instrument to attain specific social goals. The adaptive or functional quality helps us to reconstruct the cultural and anthropological rooting of the ritual and relates positively with the social function of worship. Rituals have virtually numerous qualities, and the result of academic research of social functions of liturgical ritual is therefore not unequivocal; it is and stays ambivalent and ambiguous. Worship has a performative power. Its functional aspects refer to specific aspects of religion. Some of the many qualities of liturgical ritual point to social ethical ends. The image as a whole is ambivalent and not unequivocal. We definitively have moved beyond the times of big theories, viz. functionalism. Liturgical ritual studies primarily result in carefully elaborated ideographies, and less in nomotheses. Such ideographies however presuppose a particular kind of research methodology, which in turn is based on an epistemology as proposed by Jennings and McGann.

\section{Acknowledgements}

\section{Competing interest}

The authors declare that they have no financial or personal relationship(s) which may have inappropriately influenced them in writing this article.

\section{Authors' contributions}

The largest section of the article was drafted by M.B. (University of Pretoria), except for the descriptions of the cases of liturgical ritual in Mlazi and Langa and certain parts of the theory on ritual, which were drafted by C.W. (University of Pretoria). The authors discussed the draft thoroughly, after which it was reworked by the first author.

\section{References}

Astley, J., 1984, 'The role of worship in Christian learning', Religious Education 79(3), 243-251. http://dx.doi.org/10.1080/0034408400790208

Auffahrt, C. \& Mohr, H., 2006, 'Religion', in K. Von Stuckrad (ed.), The Brill Dictionary of Religion, vol. 3, pp. 1607-1619, Leiden, Boston.

Augsburg Confession, viewed 20 April 2012, from http://bookofconcord.org/ augsburgconfession.php.

Barfield, T., 1997, The Dictionary of Anthropology, Blackwell Publishers, Malden, MA.

Barnard, M. \& Postma, E., 2007, 'Het ludieke en het rituele: Johan Huizinga's “Homo Ludens" herlezen', Theologisch Debat 4(2), 4-14.

Brouwer, R., 2009, Geloven in gemeenschap: Het verhaal van een protestanse geloofsgemeenschap, Kok, Kampen.

Calvin, J., Institution of the Christian Religion, transl. H. Beveridge, W.B. Eerdmans, Grand Rapids, MI.

Cilliers, J.H., 2008, 'Liturgie as spel: 'n Besinning oor die nie-funksionaliteit van die erediens', Nederduits Gereformeerde Teologiese Tydskrif 49(3/4), 40-48.

Cilliers, J. \& Wepener, C.J., 2007, 'Ritual and the Generation of Social Capital in Contexts of Poverty: A South African Exploration', International Journal of Practical Theology 11, 39-55. http://dx.doi.org/10.1515/IJPT.2007.4
Grimes, R.L., 2000, Deeply into the Bone: Re-inventing rites of Passage, University of California Press, Berkeley/ Los Angeles/London.

Grimes, R.L., 1990, Ritual Criticism: Case Studies in its Practice - Essays on its Theories, University of South Carolina Press, Columbia, SC.

Guardini, R., 1959, Vom Geist der Liturgie, Verlag Herder, Freiburg.

Huizinga, J., 1940, Homo Ludens: Proeve eener bepaling van het spel-element der cultuur, Tjeenk Willink, Haarlem.

Jennings, T.W. (Jnr), 1996, 'On Ritual Knowledge', in R.L. Grimes (ed.), Readings in Ritual Studies, pp. 324-334, Prentice Hall, Upper Saddle River, NJ.

Kant, I., [1787]1998, Kritik der reinen Vernunft, Nach der ersten und zweiten Original Ausgabe neu herausgegeben von Raymund Schmidt, Felix Meiner Verlag, Hamburg.

Lang, B., 1997, Sacred Games: A History of Christian Worship, Yale University Press, New Haven/London.

Mbaya, H., 2011, 'The socio-practical dimensions of isitshisa [burning of the heifer] in the Corinthian Church of South Africa', HTS Teologiese Studies/Theological Studies 67(2), Art. \#930, 8 pages. http://dx.doi.org/10.4102/hts.v67i2.930

McGann, M., 2010, 'Liturgical musical ethnography: Challenges and promise', Jaarboek voor liturgie-onderzoek 26, 83-98.

Morgenthaler, S., 1995, Worship Evangelism: Inviting unbelievers into the Presence of God, Zondervan, Grand Rapids, MI.

Müller, B.A., 2008, 'A Missional Understanding of the Church, its Ministry: Especially with Regard to its Christ Centric Liturgical Reorientation', Nederduitse Gereformeerde Teologiese Tydskrif 49(1/2), 53-65.

Platvoet, J.G., 2007, 'Ritual: Religious and Secular', in J. Kreinath, J. Snoek \& M. Stausberg (eds.), Theorizing Rituals: Issues, Topics, Approaches, Concepts, vol. 1 pp. 161-205, Leiden, Brill.

Pieterse, H., 2001, Preaching in a context of poverty, Unisa Press, Pretoria.

Post, P., 2001a, 'Ritualiteit als symboolhandelen \& Ritualiteit: Drie illustraties, drie teksten', in M. Barnard \& P. Post (reds.), Ritueel bestek: Antropologische kernwoorden van de liturgie, pp. 33-46, Meinema, Zoetermeer.

Post, P., 2001b, 'Feast as a Key Concept in Liturgical Studies', in P. Post, G. Rouwhorst, L. van Tongeren \& A. Scheer (eds.), Christian Feast and Festival: The Dynamics of Western Liturgy and Culture, Liturgia Condenda 12, pp. 47-78, Sterling/Peeters, Lestern Liturgen/Paris.
Leuve

Rhum, M., 1997, S.v 'Emic and etic', in Th. Barfield (ed.), The dictionary of Anthropology, pp. 148, Blackwell Publishers, Malden, MA.

Smit, D., 2004, 'Lex orandi, lex credendi, lex (con)vivendi? - Oriënterende inleiding tot liturgie en etiek', Dutch Reformed Theological Journal 45(3/4), 887-907. (NGTT).

Sonnenberg, R. \& Barnard, M., 2012, 'Christian Youth Worship educating young people. Reclaiming space for learning in liturgical contexts', HTS Teologiese Studies/Theological Studies 68(2), Art. \#1111, 8 pages. http://dx.doi.org/10.4102/ hts.v68i2.1111

Staal, F., [1979] 1996, 'The Meaninglessness of Ritual', originally printed in Numen 26(1), 2-22, reprinted in R.L. Grimes (ed.), 1996, Readings in Ritual Studies, Prentice Hall, pp. 483-494, Upper Saddle River, New Jersey.

Thomas, G., 2006, 'Communication', in J. Kreinath, J. Snoek \& M. Stausberg (eds.), Theorizing Rituals: Issues, topics, approaches, concepts, pp. 321-343, Brill, Leiden/ Boston.

Van Ruler, A.A., 1970, Waarom zou ik naar de kerk gaan?, Callenbach, Nijkerk.

Warren, R., 1995, The Purpose Driven Church. Growth without Compromising your Message and Mission, Zondervan, Grand Rapids, MI.

Warren, R., 2002, The Purpose Driven Life: What on Earth Am I Here For?, Zondervan, Grand Rapids, MI.

Wepener, C.J., 2002, 'Still because of the weakness of some? - A descriptive exploration of the Lord's Supper in South Africa, 1948-2002', Jaarboek voor liturgie-onderzoek 18, 139-158.

Wepener, C.J., 2004, 'Van vas tot fees: 'n Ritueel-liturgiese ondersoek na versoening binne Suid-Afrikaanse kultuurkontekste', D.Th. proefskrif, Departement Praktiese Teologie en Missiologie, Universiteit van Stellenbosch.

Wepener, C.J., 2008, 'Toward Missional Liturgy', Nederduitse Gereformeerde Teologiese Tydskrif 49(1/2), 206-219.

Wepener, C.J., 2010a, 'Liturgical research in a changing South African socio-cultural (liturgical) landscape: challenges and opportunities for method and theory', in I. Swart, S. Green \& J. Erasmus (eds.), Religion and Social Development in PostApartheid South Africa: Perspectives for Critical Engagement, pp. 403-415, SUN Press, Stellenbosch.

Wepener, C.J., 2010b, 'Snert: Ritual-liturgical measurements and recipes for socia capital', Verbum et Ecclesia 31, 1-7.

Wepener, C.J. \& Cilliers, J.H., 2004, 'In herinnering aan die kinders wat aan honger en koue moet sterf: Liturgie in ' $n$ 'konteks van armoede', Nederduits Gereformeerde Teologiese Tydskrif 45(2), 364-372.

Wepener, C.J. \& Cilliers, J.H., 2010, 'Ritual and the generation of social capital in contexts of poverty', in I. Swart, S. Green \& J. Erasmus (eds.), Religion and Social Development in Post-Apartheid South Africa: Perspectives for Critical Engagement pp. 417-430, SUN Press, Stellenbosch.

Wepener, C.J., Swart, I., Ter Haar, G. \& Barnard, M., 2010, 'The role of religious ritual in social capital formation. Theoretical and methodological points of departure of a South African exploration in progress', Religion \& Theology 17(1/2), 61-82. http:// dx.doi.org/10.1163/157430110X517924 